NBER WORKING PAPER SERIES

\title{
GLOBALIZATION AND INEQUALITY: HISTORICAL TRENDS
}

\author{
Kevin H. O’Rourke \\ Working Paper 8339 \\ http://www.nber.org/papers/w8339 \\ NATIONAL BUREAU OF ECONOMIC RESEARCH \\ 1050 Massachusetts Avenue \\ Cambridge, MA 02138 \\ June 2001
}

Revised version of a paper presented at the Annual World Bank Conference on Development Economics, 1-2 May, 2001. Parts of the paper draw on Findlay and O'Rourke (2001) and O'Rourke and Williamson (1999). I am grateful to my co-authors for permission to draw on our joint work I am also grateful to Don Davis, Tim Hatton, Richard Kohl, Philip Lane, Gregor Noll, Alan Taylor, Jeff Williamson, and two anonymous referees for helpful comments and useful conversations about these and related matters. The usual disclaimer applies. The views expressed herein are those of the author and not necessarily those of the National Bureau of Economic Research.

(C) 2001 by Kevin H. O'Rourke. All rights reserved. Short sections of text, not to exceed two paragraphs, may be quoted without explicit permission provided that full credit, including (C) notice, is given to the source. 
Globalization and Inequality: Historical Trends

Kevin H. O’Rourke

NBER Working Paper No. 8339

June 2001

JEL No. F0, N7

\begin{abstract}
$\underline{\text { ABSTRACT }}$
This paper surveys trends in both international economic integration and inequality over the past 150 years, as well as the links between them. In doing so, it distinguishes between (a) the different dimensions of globalization; and (b) between-country and within-country inequality. Theory suggests that globalization will have very different implications for within-country inequality, depending on the dimension of globalization involved (e.g. trade versus factor flows), on the country concerned, and on the distribution of endowments; the historical record provides ample evidence of this ambiguous relationship.

Late 19th century globalization had large effects on within-country income distribution, but the effect on inequality differed greatly across countries: both trade and migration (but not capital flows) made the rich New World more unequal, and the (less rich) Old World more equal. The evidence on the links between within-country inequality and globalization in the late 20 th century is mixed. The balance of evidence suggests that globalization has been a force for between-country convergence in both the late 19th and late 20th centuries; long run patterns of divergence are due to other factors (e.g. the unequal spread of the Industrial Revolution).
\end{abstract}

Kevin H. O’Rourke

Department of Economics

Trinity College

Dublin 2, Ireland

and NBER 


\section{Introduction}

Does globalization lead to the world becoming a more equal place, or does it lead to the rich getting richer and the poor getting poorer? This question has assumed ever-greater importance with the emergence of the WTO as a force for trade liberalization throughout the world, with Europe moving towards increased economic integration, with the collapse of communism and the opening up of previously autarkic economies, and with renewed speculation regarding the formation of a pan-American free trade area. The question is increasingly being raised by opponents of globalization, but public debate on the issue can be frustratingly confused. Protestors are often vague about what globalization is, and fail to recognize that globalization has different dimensions, which may have different effects on inequality. Most seriously, they often define 'globalization' as encompassing many different phenomena, some of which have little or nothing to do with globalization as economists would define it (Rodrik 2000). Globalization as economists define it encompasses declining barriers to trade, migration, capital flows, foreign direct investment (FDI), and technological transfers. This paper will restrict itself to exploring the historical links which have existed between trade, migration and capital flows, on the one hand, and inequality on the other.

The paper will also distinguish between two separate dimensions of inequality: betweencountry inequality and within-country inequality. ${ }^{1}$ If we take the appropriate unit of observation to be the individual citizen anywhere in the world, then total world inequality will clearly depend on both between- and within-country inequality, with globalization potentially affecting both through quite different channels. What these channels might be will be the subject of a theoretical overview in the following section. The paper will then trace the evolution of globalization during the $19^{\text {th }}$ and

${ }^{1}$ In so doing it is following in the footsteps of Lindert and Williamson (2001). 
$20^{\text {th }}$ centuries, distinguishing between the different dimensions involved. The next section will briefly document both types of inequality trend over the past two centuries. Finally, the paper will explore in greater detail the inequality experiences of the two most dramatic globalization episodes, the late $19^{\text {th }}$ and late $20^{\text {th }}$ centuries, and document what is known about the links between globalization and inequality during these two periods. It will then conclude with suggestions for further research.

\section{Globalization and inequality: theoretical connections}

\section{Globalization and Within-Country Inequality}

Our intuitions regarding the links between international economic integration and income distribution arise for the most part from the static neoclassical trade theory developed by Eli Heckscher and Bertil Ohlin in the early years of the $20^{\text {th }}$ century. Their basic insight was that trade patterns reflect differences in the distribution of endowments across countries, and that countries export goods embodying those factors of production with which they are well-endowed. Commodity market integration therefore leads to an increase in the demand for abundant (and cheap) factors of production, thus raising their price, while trade leads to the demand for scarce (and expensive) factors of production falling, thus lowering their price.

In a simple two-country two-factor two-good setting, with identical technology in both countries, trade and factor mobility should have identical effects on factor prices, and hence on income distribution. If the US is abundant in skilled labour, and Mexico is abundant in unskilled labour, then trade will increase US skilled wages, and Mexican unskilled wages; and it will lower US unskilled wages, and Mexican skilled wages. Thus trade leads to greater wage inequality in the US, and lower wage inequality in Mexico. It is also true, of course, that the migration of unskilled 
workers from Mexico to the US, or of skilled workers from the US to Mexico, will have identical effects on factor prices.

Things get more complicated once we move away from this very simple $2 \times 2 \times 2$ framework. For example, if the US economy has superior technology, or superior endowments of a third factor of production, so that US skilled wages are higher than Mexican wages, rather than lower, then while trade and unskilled migration may both raise wage inequality in the US and lower it in Mexico as before, skilled migration will also be from South to North, and will have the opposite effect on wage inequality in the two countries. In this case, some dimensions of globalization (trade and unskilled migration) have very different implications for inequality than others (skilled migration). Alternatively, it is important to recognize that not all developing countries (DCs) are identical: rather, they differ greatly in their endowments of capital, labour and skills (Davis 1996). The implication is that a middle-income country such as Mexico might be skill-abundant relative to countries like China and India; they might therefore protect their unskilled-labour-abundant sectors; and they might thus see skill premia rising on liberalization. There is in fact evidence that unskilled-labourintensive sectors received the most protection in countries such as Mexico and Morocco prior to liberalisation (Currie and Harrison 1997; Hanson and Harrison 1999).

A third possibility is that liberalization and FDI might lead to new skill-intensive activities being introduced into DCs (Feenstra and Hanson 1996): under such circumstances, the relative demand for skilled labour would rise in the South. Finally, capital inflows to the DCs might increase the demand for skilled labour, if skilled labour is complementary to capital, and thus raise wage inequality; alternatively, if skilled labour and capital are complementary to some natural resource (e.g. minerals), then liberalization in a resource-rich DC might also increase skill premia and 
inequality overall (Kanbur 1999).

Thus far, the discussion has assumed that the only factors influencing the impact of globalization on inequality are countries' endowments and their technology. There is another crucial factor, however, which should be mentioned: the distribution of those endowments among a country's citizens. Take for example a positive trade shock in a land-abundant country, which raises the returns to land. Clearly, if land holdings are concentrated among a few large land-owners, this shock is likely to be a force for greater inequality. On the other hand, if the land belonged exclusively to poor peasant proprietors, such a shock might well imply greater equality. The fact that trade theory implies a link between globalization and factor prices, rather than inequality per se, with the distribution of endowments intervening between the two, is one of the problems facing applied researchers seeking to explain the behaviour of summary inequality measures such as the Gini coefficient.

In conclusion: the links between globalization and within-country income distribution are ambiguous. First, globalization affects factor prices differently in different countries, for standard Heckscher-Ohlin reasons. Second, different dimensions of globalization (e.g. trade versus factor flows) may have different implications for factor prices in a given country. Third, a given dimension of globalization (e.g. capital flows) may have ambiguous effects on factor prices in a given country, depending inter alia on patterns of complementarity or substitutability between factors of production. Finally, a given impact on factor prices can have different effects on inequality, depending on the distribution of endowments across individuals.

Ultimately, these are issues which can only be resolved empirically. 


\section{Globalization and Between-Country Inequality}

Static trade-theoretic arguments suggest that globalization affects factor prices in the first instance. However, these arguments also have implications for between-country inequality, in that, other things being equal, factor price convergence should bring per capita incomes closer together. Typically, however, between-country inequality is discussed in the context of dynamic growth theory, rather than static trade theory. Models endogenising the long-run growth rate, which have been developed in the past decade, are capable of deriving long-run growth effects of a number of policies, including trade policy. Their conclusion is that the implications of trade liberalization for convergence are theoretically ambiguous.

Numerous examples could be cited, but two will suffice. Both Stokey (1991) and Grossman and Helpman (1991, Chapters 6, 9) assume that North-South trade is driven by differences in relative endowments of skilled and unskilled labour; and both assume that trade drives factor price convergence, with wage inequality rising in the North and falling in the South. In Stokey's model, the growth mechanism is individuals investing in human capital: when trade leads to returns to skill in a small DC being lowered, this can reduce the incentive to acquire skills, and hence the DC growth rate. Trade may thus lead to divergence. However, Grossman and Helpman take the endowment of human capital as exogenous, and assume that human capital is useful in that it is an input into R\&D, which drives the growth process. In such a scenario, trade which lowers DC skilled wages, and increases developed country skilled wages, boosts DC technical progress, and lowers developed country technical progress, in that the cost of innovation declines in the DC (and increases in the developed country): trade leads to convergence.

Once again, these issues can only be resolved empirically. 


\section{Trends in International Economic Integration}

To casual commentators it seems obvious that today's globalization is unprecedented. However, the late $19^{\text {th }}$ century was also a period of dramatic globalization, and the world economy was extremely well integrated in 1914 , even by late $20^{\text {th }}$ century standards (O'Rourke and Williamson 1999). War brought all this to an end, and despite the efforts of politicians and organisations such as the League of Nations, the interwar period was to see further retreats into protectionism, the erection of barriers to immigration, the final breakdown of the gold standard, and a wave of international defaults. To a large extent, post-1945 integration can be seen as an attempt to recoup the losses of the interwar period: the question then becomes, at what point were these losses finally recouped, and when did integration start to progress beyond the levels achieved in 1914? I begin with a survey of commodity market integration (CMI), before progressing to international capital and labour markets.

\section{International Commodity Market Integration}

The $19^{\text {th }}$ century saw a series of dramatic technological developments which were to have a profound impact on international trade, chiefly the steamship and railroad. The impact on transport costs was substantial: Knick Harley's index of British ocean freight rates remains relatively constant between 1740 and 1840 , before dropping by about $70 \%$ between 1840 and 1910 . International transport costs probably fell by 45 percentage points between 1870 and 1913, while transport costs between the American Midwest and East Coast fell even more dramatically than transAtlantic transport costs (O’Rourke and Williamson 1999).

Until the 1870 s, trade policy reinforced these trends. Britain liberalized from 1815 to 1846 , 
when she took the decisive step towards free trade. The years after 1860 saw significant European tariff-cutting: for example, by 1877 Germany "had virtually become a free trade country" (Bairoch 1989 , p. 41). In the late 1870s, however, cheap New World and Russian grain began depressing European land values, sparking a powerful Continental protectionist response. In the US, Northern victory in the Civil War ensured high levels of protection for the rest of the century. On the other hand, in Asia declining transport costs did not have to contend with rising tariffs: China, Japan, Korea, Thailand, India and Indonesia all moved towards free trade, most forced to do so by colonial dominance or gunboat diplomacy.

What were the combined effects of transport cost and trade policy developments in the late $19^{\text {th }}$ century? To answer this question we need to focus on international commodity price gaps, and the evidence is striking (O'Rourke and Williamson 1999, Chapter 3). Trend estimates based on Harley's (1980) data show that Liverpool wheat prices exceeded Chicago prices by $58 \%$ in 1870 , by $18 \%$ in 1895 , and by $16 \%$ in 1913 . Nor was this Anglo-American price convergence limited to the grain market: it can also be documented for bacon, cotton textiles, iron, copper, hides, wool, coal, tin and coffee. On the European Continent, tariffs impeded international price convergence, but in Asia trade policy strengthened the impact of technological developments: the cotton price spread between London and Bombay fell from $57 \%$ in 1873 to $20 \%$ in 1913, while the jute price spread between London and Calcutta fell from $35 \%$ to $4 \%$, and the rice price spread between London and Rangoon fell from $93 \%$ to $26 \%$ (Collins 1996). CMI in the late $19^{\text {th }}$ century was both impressive in scale, and global in scope: indeed, Third World economies were becoming more rapidly integrated with the rest of the world than their Atlantic economy counterparts during this period (Williamson 2000). 
Transport costs continued to fall during the $20^{\text {th }}$ century, but at a slower rate. Isserlis (1938)

provides an index of British tramp freight rates from 1869 to 1936 . Between 1869/71 and 1911/13 real trend freight rates fell by 34 percentage points. They increased sharply during the war, remaining abnormally high until 1920 . While they fell up to 1925 , they never attained their prewar levels, and rose thereafter, with the overall trend between 1921 and 1936 being broadly flat (at a level roughly equal to the 1869 level: Findlay and O'Rourke 2001).

What of the post-1945 period? In the most careful study of the subject to date, David Hummels (1999) concludes that ocean freight rates have actually increased. On the other hand, air freight rates declined dramatically in the 1950 s, 1960 s and 1980s, while declining more slowly in the 1990 s, and rising in the 1970 s. The result, predictably enough, has been a more than ten-fold increase in the ratio of air to ocean shipments in the years since 1962.

Relative to the $19^{\text {th }}$ century, it thus follows that trade liberalization has played a much greater role in late $20^{\text {th }}$ century CMI. Table 1 gives average tariffs on manufactured products in a number of countries for which data are available back to 1913. It shows the interwar rise in protection, and the decline in tariff barriers since 1950. It also shows that for most of these countries tariffs are much lower today than in 1913. There are exceptions, however, notably Britain and certain Asian countries. Both China and India, for example, have much higher tariffs now than in 1913: an extremely important qualification, given these countries' share of world population. Tariffs are much higher now in DCs than in rich countries, while the opposite was true of the late $19^{\text {th }}$ century (although there have been substantial declines in Latin American tariffs since the early 1980s, and smaller declines in East Asia: Rodrik 1999).

Moreover, emphasising industrial tariffs overstates the extent to which industrial countries 
today have moved toward free trade, for two reasons. First, agricultural protection is very high in many rich countries (and higher than in 1913). Coppel and Durand (1999) report that it raises prices received by farmers by about $60 \%$ in Japan, $40 \%$ in the European Union, $15 \%$ in Canada, and $20 \%$ in the United States. Second, non-tariff protection (such as quotas, VERs, and technical barriers to trade) is much more prevalent today than a hundred years ago.

What have been the combined impact of the transport cost and trade policy developments documented above? Price gaps for identical commodities in different markets remain the best measure of market integration, but very little work has been done documenting these for the $20^{\text {th }}$ century; moreover, obvious international sources of price data (e.g. the commodity price data to be found in the World Bank Development Indicators or the IMF's International Financial Statistics) reveal no discernable general trend towards commodity price convergence during the past four decades (Findlay and O'Rourke 2001).

Overall, what can we conclude about CMI over the past 150 years? First, the late $19^{\text {th }}$ century probably saw more dramatic progress towards CMI than did the late $20^{\text {th }}$ century. ${ }^{2}$

Second, commodity markets are probably even better integrated today, but we do not have the empirical evidence to document this. Clearly, we need further research on this important issue.

\section{International Capital Market Integration}

Capital exports from the centre to the periphery were enormous in the late $19^{\text {th }}$ century (O'Rourke and Williamson 1999, Chapter 11). The share of British wealth overseas in 1870 was

${ }^{2}$ Indeed, Baier and Bergstrand (2001) report that two-thirds of the late $20^{\text {th }}$ century trade boom can be accounted for by income growth, suggesting that CMI had little to do with it. O'Rourke and Williamson (2001) find something similar for the 1500-1800 period, which saw little or no CMI. There is no similar accounting for the rapidly globalizing $19^{\text {th }}$ century, however. 
$17 \%$, and it had increased to an impressive $33 \%$ in 1913 . The flows were extremely large during peak years: as a share of British GDP they were $7.7 \%$ at the 1872 peak, $6.9 \%$ in 1888 , and $8.7 \%$ in 1911. No OECD country, including the US, exported capital to that extent in the late $20^{\text {th }}$ century. For example, Japanese and German current account surpluses in the mid- and late-1980s peaked at around 4 or $5 \%$ of GDP.

Foreign capital flows were equally important at the receiving end. To give just one example, net inward foreign investment as a share of gross fixed capital formation ranged from 10 to $20 \%$ amongst the major Third World importers in the decade prior to 1984 , and was less than $10 \%$ of investment in DCs in the early $1990 \mathrm{~s}^{3}{ }^{3}$ The same statistic for the four decades between 1870 and 1910 was $37 \%$ for Canada (Jones and Obstfeld 1997), it was about $70 \%$ for Argentina, ${ }^{4}$ and perhaps as much as $75 \%$ for Mexico. By some measures, international capital flows have never been as important as they were in the late $19^{\text {th }}$ century, despite all the rhetoric about the unprecedented nature of today's globalization.

Capital flows diminished in size during the 1920s, but things would soon get worse: with the onset of the Great Depression, a wave of default in DCs ensued, and capital flows to these countries remained limited for decades thereafter. Between 1945 and 1972, most of the limited capital flows that took place did so in the form of direct government and multinational institutional investment abroad. Since 1972, the global capital market has become increasingly important, but Figure 1 places current trends into their proper historical context. It plots average current account shares in GDP (absolute values, 14 countries); while that share has been on the rise since the early

${ }^{3}$ For the latter statistic, see World Bank (2000), p.121.

${ }^{4}$ For the years 1885-1910; based on data kindly supplied by Alan Taylor. 
1970 s, it is still only half of what it was in the late 1880 s.

Figure 1 does, however, bias the picture somewhat, in that the 14 countries concerned are in the OECD, plus Argentina. Late $20^{\text {th }}$ century current account imbalances were much greater in some DCs: for example, they averaged 6.1\% of GDP in Malaysia between 1991 and 1997; 5.1\% in Romania, $13.5 \%$ in Singapore, $6 \%$ in Thailand, and $18.9 \%$ in the Sudan. By contrast, the equivalent figure for Argentina between 1910 and 1913 was 11\%, while it was $14.5 \%$ in Canada. Clearly, capital flows involving certain DCs were very high in both periods. ${ }^{5}$

So much for the size of flows: what about the extent of integration? Standard measures tell a consistent story: capital markets were highly integrated in the late $19^{\text {th }}$ century, disintegrated during the interwar period, and are only now recovering the levels of integration experienced in 1913. This U-shaped pattern is apparent in data on real and nominal interest-rate differentials (Obstfeld and Taylor 1998, 2001), while Taylor (1996) applies the Feldstein-Horioka (1980) test to historical data, and finds that global capital markets were better integrated between 1870 and 1924 than they were between 1970 and 1989.

What of the composition of these flows? Dunning (1993) estimates that about $35 \%$ of the stock of international long term debt in 1914 consisted of FDI. By contrast, FDI accounted for only $16.8 \%$ of private capital flows during $1973-81$, but $50.3 \%$ of private capital flows during $1990-97$ (World Bank 2000, p. 126). According to both Jones (1996, p. 32) and Bairoch and KozulWright (1996, p. 10), the stock of FDI reached over 9\% of world GDP in 1913, a figure only exceeded in the early 1990s (the figure stood at 16\% in 1999: UNCTAD 2000, p. xvi). FDI is more important now, but we are talking about a quantitative, not a qualitative shift.

\footnotetext{
${ }^{5}$ World Development Indicators; data kindly supplied by Alan Taylor.
} 
What proportion of these flows went to DCs? Between 1907 and 1913, British overseas lending was split evenly between what we would now consider to be rich countries (North America, Australasia and Europe, including Eastern Europe) and the rest of the world (Taylor and Williamson 1994). According to Table 2, 62.8\% of FDI was located in DCs in 1914: $32.7 \%$ in Latin America, $6.4 \%$ in Africa, and $20.9 \%$ in Asia (including $7.8 \%$ in China). These figures might suggest that $19^{\text {th }}$ century capital flows were largely directed towards poor countries, and were thus a force for convergence. Looks can be deceiving, however: late $19^{\text {th }}$ century capital flows were predominantly towards the resource-abundant New World, and were thus a source of divergence (Clemens and Williamson 2001). ${ }^{6}$

However, the late $19^{\text {th }}$ century saw a greater share of DFI going to DCs than did the $20^{\text {th }}$ century. DCs still hosted almost two-thirds of investment in 1938, but their share collapsed to less than one third by 1960 . By 1999 the figure stood at $30.1 \%$ (Table 2). Nor is this pattern limited to direct investment: according to Obstfeld and Taylor (2001) a smaller proportion of internationally mobile capital was located in poor countries in 1997 than in 1913, illustrating "an important dimension in which the globalization of capital markets remains behind the level attained under the classical gold standard" (p. 51).

Most late $19^{\text {th }}$ century investment was being used for social overhead investment, as is true of the Third World today: about $70 \%$ went into railroads, municipal sewage, telephones and other social overhead investments. Railroads alone accounted for about $41 \%$ of the total in 1913 (Feis 1930: 27). The debt was issued largely by governments, as was also true of the Third World during most of the postwar years. But governments did not do a much larger share of the borrowing then rich) then.

${ }^{6}$ Crucially, Latin American countries such as Argentina were relatively rich (and resource- 
than now: they accounted for maybe $40 \%$ of the investment flows in the late $19^{\text {th }}$ century. By 1930 or so, $62 \%$ of London-based lending, and $80 \%$ of New York lending, was going to governments; governments got $80 \%$ of the flows as late as 1980 , but only $33 \%$ in 1997 (World Bank 2000, p. 127). In this respect, once again, the late $20^{\text {th }}$ century has returned to late $19^{\text {th }}$ century patterns.

However, the sectoral composition of capital flows has broadened, with far more going into industry and finance in the late $20^{\text {th }}$ century than was true of the earlier period. This is certainly true of portfolio flows. In terms of FDI flows, in 1914 about $55 \%$ of the accumulated FDI stock was in the primary product sector; $20 \%$ in railroads; $15 \%$ in manufacturing; and $10 \%$ in trade, distribution, public utilities and banking (Dunning 1993, p. 116). By contrast, in the 1990 s only about $6 \%$ of EU FDI went to the primary sector, but $31 \%$ to manufactures, and $63 \%$ to services (Baldwin and Martin 1999, p. 19), while about half of US FDI is in services, and about $35 \%$ in manufacturing (Bordo, Eichengreen and Irwin 1999). The issue is important, since FDI can serve as a vehicle for technological transfer and thus hasten international convergence, as it did in Ireland during the 1990s. The changing sectoral composition of FDI over time suggests that FDI is probably playing a more important role in this regard in the late $20^{\text {th }}$ century than it did in the late $19^{\text {th }}$ (although this is mere speculation).

Furthermore, the composition of portfolio flows has changed dramatically. In the late $19^{\text {th }}$ century such flows were overwhelmingly accounted for by bonds. During the lending boom of the 1970s, by contrast, bank lending accounted for almost two-thirds of the total flow, with both bond issues and portfolio equity flows being minimal. During the 1990s, the composition of flows has become far more balanced, with an almost equal split between direct and portfolio flows, and a fairly equal division within portfolio flows between bank lending, bond issues, and equity finance 
(World Bank 2000, p. 126).

This broader range of financial assets traded clearly distinguishes the late $19^{\text {th }}$ and late $20^{\text {th }}$ centuries, as does the greater share of investment today in manufacturing and services. Other differences, highlighted by Bordo, Eichengreen and Kim (1998), include the huge volume of gross capital flows today. Although clear evidence on the late $19^{\text {th }}$ century is lacking, it seems certain that the ratio of gross to net capital flows is much greater now than then, reflecting greater volumes of short run capital flows. Presumably, however, net long run flows matter more than gross short run

flows for growth and income distribution. Finally, while much late $19^{\text {th }}$ century FDI was undertaken by 'free-standing companies', incorporated in the core in order to carry on business within the periphery, FDI today occurs overwhelmingly within multinational corporations which do business in both home and host countries.

\section{International Migration}

It is in the area of migration that the late $19^{\text {th }}$ century seems most clearly to have been more globalized than today. Although barriers to immigration were being erected by the end of the period (O'Rourke and Williamson 1999, Chapter 10), by and large the late $19^{\text {th }}$ century stands out as a relatively liberal interlude in terms of migration policy; once transport costs had fallen sufficiently relative to the average wage, the inevitable consequence was a huge intercontinental flow of people. Between 1820 and 1914, roughly 60 million Europeans emigrated to the New World; European emigration averaged 300,000 per annum in the three decades after 1846 , more than doubled in the next two decades, and exceeded a million after the turn of the century (Hatton and Williamson 1998). Some of the country-specific migration rates were enormous: during the 1880 s, the 
emigration rate per thousand was 141.7 in Ireland, and 95.2 in Norway, while the immigration rate per thousand was 85.8 in the United States, and 221.7 in Argentina. In the first decade of the $20^{\text {th }}$ century, emigration rates of 107.7 per thousand were recorded in Italy, while immigration rates per thousand were 167.6 in Canada, 118.4 in Cuba, 102 in the United States, and 291.8 in Argentina. There were also significant migrations within Europe and the New World, and emigration from Asia.

The UN has estimated that the world stock of migrants was $2.3 \%$ of the total world population in both 1965 and 1990. Within Western Europe, the share of migrants in the total population increased from $3.6 \%$ to $6.1 \%$ over the same period, while within North America, the migrant share increased from $6 \%$ to $8.6 \%$ (Zlotnik 1999, Table 1a, p. 47). By contrast, the foreign born accounted for $14.7 \%$ of the population of the United States, and $22 \%$ of the Canadian population in 1911 (US Department of Commerce 1975, p. 14; Historical Statistics of Canada series A260-61). Annual immigration to the United States averaged 770,000 during 1990-94 and 814,000 during $1995-96$, implying decadal immigration rates of roughly 30 per thousand. Immigration in the early 1990s was proportionally higher in Canada, which saw decadal immigration rates of 70 to 80 per thousand in the early 1990 s; rates of around 80 per thousand were also recorded in Germany during 1990-94; while rates of around 50 per thousand were recorded in both Germany and Australia during 1995-96. These are clearly fairly substantial flows, but they are dwarfed by those of the late $19^{\text {th }}$ and early $20^{\text {th }}$ century.

Once again, however, a caveat is in order. Labour market integration cannot be measured by the size of flows alone: the responsiveness of migration to given wage differentials is a better measure. Several papers have compared inter-regional migration responsiveness across countries, in the context of the debate on EMU (e.g. Eichengreen 1993; Obstfeld and Peri 1998); but hardly 
any have calculated the changing responsiveness of migration to migration incentives over time. An exception is Hatton and Williamson (2001), which compares African (intra-continental) migration elasticities with the (inter-continental) elasticities obtaining in late $19^{\text {th }}$ century Europe, and finds little difference between the two periods. More work along these lines is required before we can make definitive statements about trends in labour market integration over time.

Mass migration will have the greatest impact on between-country equality if it transfers population from poor to rich countries. In the late $19^{\text {th }}$ century, migration was clearly of this form, since Europe was significantly poorer than the New World; however, emigration was initially higher from the richer European regions, with the poorer southern and eastern regions only becoming involved with a lag. Something similar appears to have taken place in the late $20^{\text {th }}$ century (Chiswick and Hatton 2001). For example, the share of DC migrants in total US immigration rose from $50 \%$ in the $1960 \mathrm{~s}$, to $63 \%$ in the $1970 \mathrm{~s}, 86 \%$ in the $1980 \mathrm{~s}$, and $80 \%$ in the early 1990 s (Zlotnik 1999 , Table 3). Similar trends are apparent in Canada, Australia and Europe (where migration from Eastern Europe has increased over time). Thus, in both periods mass migration was increasingly involving poorer countries, and thus potentially making a bigger contribution to convergence; the big question for the $21^{\text {st }}$ century is to what extent will Africa begin participating in mass, intercontinental migration (Hatton and Williamson 2001).

The impact of migration on within-country inequality largely depends on the skill mix, as was suggested above. In the late $19^{\text {th }}$ century, migration predominantly involved young, unskilled adults, with very high labour force participation rates; it thus had a large potential impact on inequality, lowering it in Europe and raising it in the New World. As the late $20^{\text {th }}$ century progressed, the picture became increasingly similar, at least for the US: the skill profile of immigrants, relative to the 
native born, has declined dramatically since the mid-1960s (Borjas 1999, Chapter 2). ${ }^{7}$ In several countries, however, policy has responded by encouraging more skilled immigration, often via temporary work permit programmes. In principle, this could lead to greater inequality in emigrant economies, and greater equality in immigrant countries: the opposite of what occurred in the late $19^{\text {th }}$ century.

\section{Inequality Trends}

The previous section has documented a U-shaped trend in the extent of international economic integration, with integration in the late $19^{\text {th }}$ century, followed by disintegration in the interwar period, and a recovery since World War 2 . The recovery has been uneven, however, with some dimensions of integration remaining undeveloped relative to 1913 (e.g. migration), and with some countries not participating as fully in the recovery as others (in particular, certain DCs). The question now arises: what has been the inequality experience over the past two centuries, and to what extent can this experience be related to globalization trends?

The benchmark study of world income inequality trends over the past two centuries is a recent paper by François Bourguignon and Christian Morrisson (1999), which makes use of data on population, real GDP per capita, and vintile shares for 33 groups of countries between 1820 and 1992. Figure 2 plots the resulting Theil coefficients for total world inequality, as well as a decomposition into that portion explained by between-country inequality, and that portion explained by within-country inequality. Several key lessons emerge from the figure.

First, world inequality has increased substantially since 1820 . Between 1820 and 1910, a

${ }^{7}$ Indeed, a higher proportion of immigrants were high school dropouts in 1998 than in 1990, reversing a steady downward trend in this figure since 1960 (Borjas 1999, p. 21). 
period of rapid growth and globalization, the Theil coefficient rose from 0.533 to 0.799 , a rise of $0.226(0.025$ per decade) or $50 \%$. Inequality remained fairly stable between 1910 and 1960 , dipping during the 1950s, before resuming its rise after 1960, another period of rapid growth and globalization. Between 1960 and 1992, the Theil coefficient rose by 0.093 ( 0.027 per decade, roughly the same rate as the $19^{\text {th }}$ century figure), or by $12 \%$.

Second, the rise in total inequality over the period as a whole has been entirely driven by a rise in inequality between countries; indeed, within-country inequality declined over the period. Between-country inequality rose continuously from 1820 to 1950 ; it fell during the 1950 s and 1970 s, but rose during the 1960 s and 1980s, and rose over the post- 1960 period as a whole. This confirms Pritchett's (1997) finding that divergence, rather than convergence, characterises the long run aggregate growth record.

Third, the cessation of the trend towards greater overall inequality during the interwar period was not due to more favourable between-country inequality trends, since between-country inequality continued to rise rapidly. Rather, it was due to a dramatic decline in within-country inequality, which fell from 0.500 in 1910 to 0.323 in 1950 , a 0.177 decline (or 35\%) in 4 decades, or a 0.044 point decline per decade. It seems as though this interwar experience was an aberration, since within-country inequality trended very gently and continuously upwards both before 1910 and after 1950. Over the period as a whole, within-country inequality has declined sharply, as a result of this apparent step decline during the interwar period, and this is in clear contrast to between-country inequality, which has increased sharply.

Fourth, while within-country inequality was the dominant force driving total world inequality in 1820, its relative importance has declined over time, and since World War 2 between-country 
inequality has been the most important factor accounting for total inequality. This suggests that for those concerned with world inequality, while their focus should have been on domestic redistribution in the early $19^{\text {th }}$ century, by now it should be firmly focussed on policies designed to help poor countries converge macroeconomically on the rich.

Moreover, such convergence may at last be happening. While the long run evidence clearly points to between-country divergence, recent papers suggest that this trend was replaced by convergence at the end of the $20^{\text {th }}$ century. Melchior, Telle and Wiig (2000) calculate (populationweighted) Gini coefficients for world income distribution, using per capita income data for 115 countries. They find that the Gini coefficient fell from 0.59 in 1965 to 0.52 in 1997, with China's catch-up being crucial. Schultz (1998) finds that between-country inequality started falling from the mid-1970s; Boltho and Toniolo (1999) find that it started falling from 1980. A common feature of these papers is their use of PPP-adjusted data; the implication is that there has been what Lindert and Williamson (2001) refer to as an 'epochal turning point'. According to Schultz, the convergence since then has been strong enough that overall world inequality (both between- and within-country) has also started to decline. ${ }^{8}$

The question now arises: to what extent has globalization been responsible for any of these trends? We turn first to the globalization boom of the late $19^{\text {th }}$ century.

\section{Globalization and Inequality in the Late $19^{\text {th }}$ Century}

\section{Factor Price Trends}

As we have seen, the late $19^{\text {th }}$ century was characterised by dramatically declining transport

${ }^{8}$ But see Milanovic (1999) for a contrary view, albeit one based on only two years (1988 and 1993); see also Dowrick and Akmal (2001). 
costs; by mass migration from the Old World to the New; and by large transfers of capital from the Old World to the New. How did each of these separate dimensions of globalization influence income distribution within and between countries?

Take the evidence on factor prices first, and begin with the within-country evidence. We have abundant evidence on late $19^{\text {th }}$ century relative factor prices, compiled by O'Rourke, Taylor and Williamson (1996), and Jeffrey Williamson, in a series of papers summarized in Williamson $(1998,2000)$. These papers present data on $w / r$, the ratio of the unskilled, urban wage to the returns to agricultural land. This was the key relative factor price in an era when agriculture was still an important component of the economy, and in which inter-continental trade was largely dominated by the exchange of resource- and land-intensive products for labour-intensive products such as manufactured goods. The metaphor which motivated Heckscher and Ohlin in the first place was one of the land-abundant New World exchanging food for European manufactured goods, and their logic suggests that in times of globalization, $w / r$ should have converged internationally. In landabundant New World economies, where $w / r$ was high, it should have declined; and in land-scarce European economies, where $w / r$ was low, it should have increased. Moreover, in absolute terms low European wages should have caught up with high New World wages; while low New World land prices should have caught up with high European land prices. By and large, these predictions hold good for the late $19^{\text {th }}$ century.

Between 1870 and 1910, real land price increases in Australia (over 400\%) and the US (over $250 \%$ ) were enormous, far greater than the biggest real land price increase in this sample of European countries (Denmark, where land prices increased by $45 \%$ between $1870-73$ and 1910 13). Moreover, in three European countries -- Britain, France and Sweden -- land prices fell, in 
Britain by over $50 \%$. There was certainly absolute convergence in the returns to land during this period. Meanwhile, wages in Europe were converging on New World wages (Williamson 1995), although this absolute wage convergence was more modest in scale, and there were poor countries who did not participate in the convergence experience. The net result was that the 40 years after 1870 saw substantial relative factor price convergence, with wage-rental ratios rising in Europe, and falling in the New World, just as Heckscher and Ohlin would have predicted (Williamson 2000, Table 3). By 1910, the Australian ratio had fallen to one quarter of its 1870 level, the Argentine ratio had fallen to one-fifth of its mid-1880 level, and the US ratio had fallen to half of its 1870 level. In Europe, the British ratio in 1910 had increased by a factor of 2.7 over its 1870 level; the Irish ratio had increased by a factor of 5.6; the Swedish ratio had increased by a factor of 2.6; and the Danish ratio by a factor of 3.1. This increase was less pronounced in protectionist economies: the ratio increased by a factor of 2.0 in France, 1.4 in Germany, and not at all in Spain.

The Heckscher-Ohlin predictions were also well born out by the experience of those Third World countries which participated in the late $19^{\text {th }}$ century global economy (Williamson 2000, Table 4). In land-scarce economies such as Japan, Korea and Taiwan, the wage-rental ratio increased substantially, while it plummeted in land-abundant food exporting nations such as Argentina, Uruguay, Burma, Siam, Egypt and the Punjab. Relative factor price convergence was not limited to the present-day OECD region, it appears.

What was responsible for these trends, and in particular for the impressive wage-rental ratio convergence? O'Rourke, Taylor and Williamson (1996) explore this issue econometrically, using data for seven countries between 1875 and 1914: Australia, Britain, Denmark, France, Germany, Sweden and the US. The results are supportive of Heckscher and Ohlin: the ratio of agricultural to 
manufacturing prices has the expected negative effect on wage-rental ratios for five of the seven countries, the exceptions being Australia and Denmark. It appears that CMI was important in driving factor price convergence during this period.

Moreover, other dimensions of globalization also contributed to the wage-rental convergence; in particular, migration increased wage-rental ratios in Europe and lowered them in the New World. However, international capital flows were probably a force for divergence during this period, rather than convergence, in that capital flowed from low-wage Europe to the high-wage New World, exacerbating rather than moderating wage-rental ratio differences.

Factor Price Convergence and Inequality in the Late $19^{\text {th }}$ Century

What were the implications of these factor price movements for inequality? To a large extent, this depended on who owned the land. Typically, landowners were at the top of the income distribution, and so the globalization forces which raised wage-rental ratios in Europe should have made Europe more equal; while the same forces which lowered wage-rental ratios in the New World should have made those societies more unequal. Presumably the inequality impact was greater where land-holding was more concentrated, such as Latin America, than in societies where the family farm predominated, such as the northern United States, or Burma. Meanwhile, intercontinental migrants were typically unskilled; thus, immigration would have lowered unskilled wages and raised inequality in the New World, but raised unskilled wages and lowered inequality in Europe. Broadly speaking, globalization should have made the relatively poor Old World more equal, but at the expense of higher inequality in the affluent New World- precisely the same correlation as Heckscher-Ohlin thinking would predict today. 
Complete income distributions are typically unavailable for the late $19^{\text {th }}$ century, but Williamson (1997) constructed an alternative measure of inequality: the ratio of the unskilled wage to GDP per worker hour, $w / y$. This measure compares the income of those at the bottom of the distribution with a weighted average of all other relevant factor prices- skilled wages, but also returns to such factors as capital and land, which were highly relevant both 100 years ago and in the late $20^{\text {th }}$ century Third World. Williamson found that while inequality fell dramatically ( $w / y$ increased, from 100 in 1870 to 153 or 154 in 1913) in poor European countries like Denmark and Sweden, where $w$ was initially low, it rose substantially in rich New World economies like the US and Australia, where $w$ was initially high ( $w / y$ fell, from 100 in 1870 to 53 or 58 in 1913). Inequality also fell sharply in poor economies like Norway and Italy, while remaining more stable in the richer European economies, as well as in peripheral economies which remained aloof from globalization (such as Iberia).

The OECD evidence is thus consistent with the Heckscher-Ohlin prediction that globalization should have raised inequality in rich equal societies and lowered it in poor, unequal societies. The Third World evidence is more mixed, however. Wherever the data are available, they show $w / y$ falling during the late $19^{\text {th }}$ century- in Argentina, Brazil, Mexico, Uruguay, Japan, Burma, India, Indonesia, the Philippines, Taiwan and Thailand (Williamson 2000, Tables 4, 5). In the Latin American case, there is an explanation consistent with that given for other New World economiesglobalization lowered wage-rental ratios, which should boost inequality. Furthermore, countries such as Argentina were not low-wage by late $19^{\text {th }}$ century standards. In the Asian case, however, things are slightly more puzzling. First, inequality rose everywhere, even in undisputedly poor countries. Second, inequality rose not only in land-abundant areas such as Burma and Thailand, where wage- 
rental ratios fell, but also in land-scarce economies such as Japan and Taiwan, where wage-rental ratios rose. Presumably this anomaly is due to the fact that inequality trends were not just determined by globalization (and wage-rental ratios), but by other factors, such as demography and technological change, as well.

To summarize: there appears to be a causal relationship between globalization and withincountry inequality for this period. Trade did have an impact on wage-rental ratios, just as theory says it should. Moreover, Williamson (1997) shows that there is a strong relationship between migration flows and movements in $w / y$, with $w / y$ rising more (falling less) in countries that experienced more emigration (less immigration). However, the episode shows that the links between globalization and distribution are subtle and varied, just as was suggested earlier. First, globalization did have different effects on factor prices and inequality in different continents: trade raised $w / r$ in Europe and lowered it in the New World, and migration raised $w / y$ in Europe, and lowered it in the New World. This has to be born in mind when inspecting the average inequality trends in Figure 2: the dramatic egalitarian trends in some European countries during this period, and the equally dramatic inegalitarian trends in some New World countries at the same time, all of which were intimately linked to globalization, largely cancelled each other out in the aggregate. Thus, a regression of inequality on some measure of globalization which failed to take account of the very different links between the two variables in different continents might well incorrectly conclude that on balance there was no link between globalization and inequality. Second, different dimensions of globalization had different effects on distribution, with migration raising European wages (for example), and capital flows lowering them. Third, the impact of a given factor price change on inequality (e.g. a rise in the return to land in land-abundant countries) depended on the distribution 
of endowments, as the contrast between Burmese or Ghanaian peasants landowners, on the one hand, and Argentine estancia owners on the other, makes fairly clear.

\section{Globalization and Between-Country Inequality}

The previous sections have already touched on some themes relevant to the links between globalization and between-country convergence, so this section can be brief. Figure 2 suggested that between-country inequality rose substantially during the late $19^{\text {th }}$ century, a period of rapid globalization. Moreover, while relative factor prices were converging intemationally, and while there was absolute factor price convergence within the Atlantic economy, globally there was absolute factor price divergence, at least insofar as real wages were concerned. According to Williamson (1998, Tables 1, 2), real wages in Japan, Burma, India, Indonesia, Taiwan and Thailand all fell further behind British wages during this period, reflecting superior European growth. The question now arises: was globalization responsible?

O'Rourke and Williamson $(1997,1999)$ explore the links between globalization and convergence for a sample of European and New World economies between 1870 and 1913. Their first finding mirrors a late $20^{\text {th }}$ century one: while there may have been divergence for the world as a whole, there was convergence for this smaller sample of rich countries, although it was weak. However, it is the variety of country experiences that really stands out, rather than this general pattern: while some countries, like Ireland and Italy, converged on the leaders of the day (like the US and Britain) at about the expected rate, others (like the Scandinavians) converged much faster than expected, and still others, like the Iberians, did not converge at all.

O'Rourke and Williamson then quantify the trade, migration and capital flows shocks which 
hit these economies during the late $19^{\text {th }}$ century, and calculate the contribution of each of these forces to the patterns of convergence and divergence which the data reveal. In each case, the methodology is the same: calculate the impact of trade, or migration, or capital flows, on real wages in a peripheral country, on the one hand, and Britain and the US on the other. Infer what the impact of the shock on the real wage gap between core and periphery is, and express this change as a percentage of the total change in the wage gap. Mass migration and international capital flows explained between a third and a half of the Scandinavian catch-up on Britain, and between 48 and $88 \%$ of Scandinavia's catch-up on the USA; they explained over two-thirds of the Irish and Italian catch-up on Britain, and all of those two countries' catch-up on the USA. Moreover, the Iberian failure to converge on the leaders can in large part be attributed to their failure to import enough capital and send out enough people.

Globalization thus helped several peripheral European countries converge on the core, while insufficient globalization helps to explain Iberia's failure to converge. The crucial factor was migration, which accounted for some $70 \%$ of the total convergence experienced in the Atlantic economy during the period (Taylor and Williamson 1997); trade may have been important for within-country distribution, but it played a much more minor role insofar as between-country distribution was concerned. ${ }^{9}$ It seems as though the rising between-country inequality of the late $19^{\text {th }}$ century was not due to globalization.

\section{Globalization and Inequality in the Late $20^{\text {th }}$ Century}

The Heckscher-Ohlin model provides a good guide to the late $19^{\text {th }}$ century experience, in

${ }^{9}$ And, as mentioned, capital flows were actually a force for divergence. 
which trade was dominated by the exchange of food for manufactures, the two key regions were the Old and New Worlds, and the two key factors of production were land and labour. In the late $20^{\text {th }}$ century context, the debate has often assumed that the two key factors are skilled and unskilled labour, and that the two key regions are the North and South. Heckscher-Ohlin logic implies that, under these conditions, globalization should imply rising skill premia and inequality in the North, and falling skill premia and inequality in the South (Wood 1994).

These predictions have not been born out in practice: for example, although the HeckscherOhlin predictions were largely vindicated by the East Asian experience of the 1960s and 1970s, skill differentials seem to have widened in several Latin American countries following liberalization in the 1980s (Robbins 1996; Wood 1997). Moving away from this small, oft-studied group of countries, the most comprehensive evidence on wage dispersion which we have comes from the ILO's October Surveys, summarised in Freeman and Oostendorp (2000). Consistent with many other studies, and with Heckscher-Ohlin theory, they find sharply rising wage inequality in Britain and the US; however, as many advanced countries saw wage dispersion falling as saw it rising between the mid-1980s and mid-1990s. Moreover, regression analysis found wage differentials actually falling in rich and upper middle income countries during the 1980s and 1990s, and rising in lower middle income countries (as well as former Communist countries): the opposite correlation to what theory would predict.

On the other hand, overall inequality measures have been on the increase in most of the OECD since the 1970s, and particularly from the mid-1980s (Bumiaux and others 1998). Here again, however, there are exceptions, such as Denmark, Canada and France. The increased inequality is mostly due to widening labour earnings; as Lindert and Williamson (2001) point out, if 
labour eamings are widening but wage differentials are not, then unemployment and hours reduction must be playing a large role in driving overall OECD inequality trends.

Among DCs, the picture is mixed. Inequality has been steadily declining in Latin America from the 1960s, despite what happened to skill differentials during the 1980s (Table 3); the patterns in Africa and the Pacific Rim are rather erratic, rising between the 1960s and 1970s, falling through the 1980s, and rising again between the 1980s and 1990s. On the other hand, within-country inequality has been rising in China and India since the mid-1980s, and this should dominate any population-weighted DC inequality index (Lindert and Williamson 2001). And again, this rising within-country inequality trend in the South is not what simple $2 \times 2$ Heckscher-Ohlin models would lead us to expect.

Of course, these trends do not on their own disprove simple trade theory, since distribution is driven by many factors other than globalization. For example, political developments disfavouring unions, or the entry of China with its vast reserves of unskilled workers into the world market, or the simultaneous and unrelated introduction of new technology disfavouring unskilled workers, might account for the increased Latin wage inequality (Wood 1997). Alternatively, such factors as demography, educational developments, democratization, the collapse of Communism, and so on, may have been the most important factors influencing inequality trends. As always, we need multivariate analysis to disentangle these separate effects from each other; it is to such studies that we now turn.

Within-Country Inequality and Globalization: Cross-Country Studies Since the publication of Deininger and Squire's (1996) dataset, there has been a 
proliferation of articles exploring the determinants of late $20^{\text {th }}$ century inequality across countries and over time. Many ask whether there is support for Simon Kuznets' (1955) prediction that in the initial stages of growth structural change boosts inequality, while in the later stages inequality moderates. It is, however, the relationship between inequality and openness which concerns us here; and the literature provides ambiguous answers. For example, when Higgins and Williamson (1999) regress inequality on openness (they use the Sachs and Warner (1995) dummy variable), together with the Kuznets variables and cohort size, the coefficient has a negative, but insignificant, sign. When, in addition, openness is interacted with dummy variables indicating whether a country is either in the bottom or the top third of the international labour productivity distribution, the coefficient on openness becomes negative and significant, while the interaction terms are insignificant. The latter finding suggests that standard Stolper-Samuelson theory is not applicable; the negative effect of openness on inequality suggests that globalization has a benign effect on income equality- but it turns out, however, that the size of this effect is modest.

On the other hand, Barro (2000), using an expanded version of the Deininger-Squire data set, and a synthetic openness measure based on regressions of trade share on population, land area and trade policy, finds that openness is positively related to inequality. Moreover, an interaction term between openness and GDP per capita is negative and significant: openness raises inequality below per capita incomes of about $\$ 13,000$ (1985 US dollars), and lowers it at per capita incomes above that amount. This latter finding is of course at odds with the Heckscher-Ohlin prediction regarding trade and skill differentials.

Spilimbergo, Londoño and Székely (1999) provide the empirical analysis of the DeiningerSquire data set most closely related to Heckscher-Ohlin thinking. Factor prices are related to 
endowments and traded goods prices; the latter depend on world endowments and trade policies. In their empirical specification, inequality is related to country endowments of capital per worker, arable land per worker, and skill intensity, relative to the 'effective' world endowment of the factor in question; to these endowment variables interacted with a synthetic trade openness measure; to openness itself; and to income and income squared.

Openness is positively correlated with inequality, although this finding is not robust to the choice of openness measure. Openness increases inequality in skill-abundant countries, consistent with the Anglo-American evidence and with the Heckscher-Ohlin model; however, openness reduces inequality in land- and capital-abundant countries, which is inconsistent with the HeckscherOhlin intuition that trade should increase the returns to land and capital in such countries, and thus raise inequality if these resources are unequally distributed.

In conclusion, the existing cross-country studies leave many questions regarding the links between openness and inequality unanswered. Spilimbergo, Londoño and Székely find that the sign of the effect depends on the choice of openness indicator; and while Higgins and Williamson find that openness is negatively associated with inequality, Barro finds a positive association. The results do not seem to be robust to either equation specification or to the choice of openness indicator. Further research clearly seems warranted, although to date the finding that openness has at most a modest impact on inequality (in either direction) seems fairly robust.

Moreover, as O'Rourke and Williamson (1999) stress, cross-country regressions can conceal as much as they reveal: the diversity of country experience is as interesting as average correlations. As we have already seen, differing relationships between openness and inequality in different countries may cancel each other out in the aggregate. Furthermore, there are many 
dimensions of openness, as we saw above, and each may have different effects on income distribution. We need to distinguish between these various dimensions of openness; see to what extent globalization has affected countries along each of these dimensions; and compute the effects of each of these shocks on inequality using well-specified economic models.

\section{Between-Country Inequality and Globalization}

An earlier section argued that there was no causal link between late $19^{\text {th }}$ century globalization and between-country divergence: rather, globalization, and in particular migration, was a force for convergence. Is the same true of the late $20^{\text {th }}$ century? If convergence has indeed replaced divergence since the mid-1980s, could globalization be responsible? In an oft-cited study, Ben-David (1993) shows that there was substantial convergence between the original EEC 6 after 1950 and argues that there is a link between intra-EEC trade liberalisation and this convergence. For example, dispersion between Ireland, the UK and Denmark increased until the mid-1960s, when they started to liberalise vis a vis each other; dispersion between the three declined after 1973, when they joined the EEC. Turning to the world as a whole, Sachs and Warner (1995) find that there is a strong tendency to convergence among countries pursuing open trade policies, but not among more closed economies.

However, these arguments are entirely post hoc ergo propter hoc. Moreover, BenDavid's argument that post-war convergence must have been due to liberalisation, as there was no convergence prior to 1945, is incorrect, as O'Rourke and Williamson (1999, Chapter 2) show, and as Rodríguez and Rodrik (2001) point out. These correlations are fascinating and suggestive, but we need rigorous model-based analysis if Ben-David's argument is to be made convincingly; 
especially since Slaughter (2001) finds no relationship between trade liberalization and convergence, using a more sophisticated difference-in-differences analysis. ${ }^{10}$

Moreover, the dimension of globalization which had the greatest impact on convergence one hundred years ago was not trade, but labour flows; political reality suggests that mass intercontinental migration will not be allowed to play the same role in the future. Capital flows and technological transfers, operating through trade or FDI (e.g. Coe and Helpman 1995; Keller 2001), will have to take up the slack. Work by Alan Taylor on Latin America (e.g. Taylor 2000) suggests that capital flows can have a major impact on peripheral economies, where policy allows these to take place; unfortunately, late $20^{\text {th }}$ century capital markets do not seem to have done as good a job at channelling savings towards DCs as their late $19^{\text {th }}$ century counterparts. Ensuring that DCs benefit from these flows will be crucial in ensuring convergence in the future.

\section{Conclusion}

What have we learned thus far?

First, globalization can have an important impact on within-country income distribution, and did during the late $19^{\text {th }}$ century. However, for the reasons outlined at the start of the paper, the relationship between globalization and inequality will vary depending on the country being considered, the dimension of globalization involved, and the distribution of endowments. The late $19^{\text {th }}$ century experience illustrates these points very clearly, and there is no reason to suppose that things are different in the $20^{\text {th }}$ century. It follows that searching for average relationships between

${ }^{10}$ Furthermore, Rodríguez and Rodrik (2001) have cast doubt on the Sachs-Wamer dummy variable; while it is always possible that countries which pursued open policies shared some other characteristic which made them more likely to converge on the core. 
summary measures of globalization and inequality across countries is a hazardous enterprise: results are likely to be sensitive to the countries chosen and the openness indicator used. In this light, the fact that the cross-country regressions surveyed above have thus far failed to yield robust correlations should come as no surprise.

Second, the $19^{\text {th }}$ century evidence indicates that globalization was positively associated with between-country convergence, although the fact that the general world environment is liberal does not ensure that poorer countries will catch up with the rich: for whatever reason, Iberia remained relatively isolated from international factor markets during this period, and paid the price. The late $20^{\text {th }}$ century evidence is, as yet, inconclusive. If globalization is indeed associated with convergence, then why did both the late $19^{\text {th }}$ and late $20^{\text {th }}$ centuries experience so much between-country divergence (at least until the 1980s)? The answer, presumably, is superior technological progress in richer countries: globalization was not the culprit. Lucas (2000) describes how divergence might coincide with globalization, in the context of a simple general model. The model assumes that countries randomly leave behind a pre-industrial past and embark on modern industrial growth, with the probability that this occurs depending on world income; and that when they do embark on such growth, they catch up on the economic leaders. The latter phenomenon may, as Lucas suggests, be due to the diffusion of resources or ideas across borders (and, by implication, be positively related to international economic integration). The model predicts a world-wide Kuznets curve, and the recent papers surveyed above suggest that while we were on the upward slope of the curve until recently, we may now have reached the turning point, and be experiencing convergence.

Third, there are many respects in which we simply do not know enough about these two phenomena, and the relationship between them. First, we do not have the commodity price data 
required to document the evolution of international commodity market integration across the $20^{\text {th }}$ century. If the $19^{\text {th }}$ century can yield such information to diligent scholars, then surely the $20^{\text {th }}$ century can do the same.

Second, we need more information on factor prices, which according to theory are what should be linked to globalization in the first place. Furthermore, we need data not just on different categories of wages, but on the returns to land and capital. It is the availability of such factor price data which has allowed economic historians to clearly uncover the links between international integration and income distribution in the $19^{\text {th }}$ century; aggregate measures of inequality, such as Gini coefficients, are too crude and are influenced by too many different factors for clean relationships to emerge cleanly from the data.

Third, when carrying out cross-country growth regressions, we need to do so in ways more consistent with trade theory. We need to interact our openness indicators with more country-level characteristics, as do Spilimbergo, Londoño and Székely; even more importantly, maybe, we need to enter different openness measures into our regressions, and see if different dimensions of globalization have different effects. It would also be helpful if regressions could be run with factor price ratios on the left hand side, rather than aggregate inequality indicators.

Fourth, we need to supplement cross-country exercises with more country studies, since the impact of globalization on inequality differs so greatly across countries.

Finally, the evidence may provide grounds for some optimism regarding future inequality trends. The rise in inequality over the past 200 years has been mostly due to a rise in betweencountry inequality, which is now the dominant cause of overall inequality. This trend may now have been reversed; and the $19^{\text {th }}$ century experience (and arguably the late $20^{\text {th }}$ century experience as 
well) suggests that this decline will be accelerated by increased globalization.

\section{References}

Baldwin, Richard E. and Philippe Martin. 1999. "Two Waves of Globalization: Superficial Similarities, Fundamental Differences." In Horst Siebert, ed., Globalisation and Labour. Tübingen: J.C.B. Mohr for Kiel Institute of World Economics.

Baier, Scott L. and Jeffrey H. Bergstrand. 2001. "The Growth of World Trade: Tariffs, Transport Costs, and Income Similarity." Journal of International Economics 53 (1): 1-27.

Bairoch, Paul. 1989. "European Trade Policy, 1815-1914." In Peter Mathias and Sidney Pollard, eds., The Cambridge Economic History of Europe, Vol.VIII. Cambridge: Cambridge University Press.

Bairoch, Paul. 1993. Economics and World History: Myths and Paradoxes. Chicago: University of Chicago Press.

Bairoch, Paul and Richard Kozul-Wright. 1998. "Globalization Myths: Some Reflections on Integration, Industrialization and Growth in the World Economy." In R. Kozul-Wright and R. Rowthorn, eds., Transnational Corporations and the Global Economy. New York: St. Martin's Press.

Barro, Robert J. 2000. "Inequality and Growth in a Panel of Countries." Journal of Economic Growth 5 (1): 5-32.

Ben-David, Dan. 1993. "Equalizing Exchange: Trade Liberalization and Income Convergence." Quarterly Journal of Economics 108 (3): 653-679.

Boltho, Andrea and Gianni Toniolo. 1999. "The Assessment: The Twentieth CenturyAchievements, Failures, Lessons." Oxford Review of Economic Policy 15 (4): 1-17.

Bordo, Michael D., Barry Eichengreen, and Jongwoo Kim. 1998. "Was There Really an Earlier Period of International Financial Integration Comparable to Today?" In The Implications of Globalization of Financial Markets. Bank of Korea.

Bordo, Michael D., Barry Eichengreen and Douglas A. Irwin. 1999. "Is Globalization Today Really Different Than Globalization a Hundred Years Ago?" In Susan Collins and Robert Lawrence, eds., Brookings Trade Policy Forum. Washington D.C.: Brookings Institution.

Borjas, George. 1999. Heaven's Door: Immigration Policy and the American Economy. Princeton, NJ: Princeton University Press.

Bourguignon, François and Christian Morrisson. 1999. "The Size Distribution of Income Among World Citizens: 1820-1990.” Mimeo, World Bank.

Burniaux, Jean-Marc, Thai-Thanh Dang, Douglas Fore, Michael Förster, Marco Mira d'Ercole and Howard Oxley. 1998. "Income Distribution and Poverty in Selected OECD Countries." OECD Economics Department Working Papers 189. Paris: OECD.

Chiswick, Barry and Timothy J. Hatton. 2001. "International Migration and the Integration of Labor Markets." Paper presented at the NBER Globalization in Historical Perspective conference, Santa Barbara, CA, May 3-6, 2001. 
Clemens, Michael A. and Jeffrey G. Williamson. 2001. "Where Did British Foreign Capital Go? Fundamentals, Failures and the Lucas Paradox 1870-1913." NBER Working Paper 8028. Cambridge, MA: National Bureau of Economic Research.

Coe, David T. and Elhanan Helpman. 1995. "International R\&D Spillovers." European Economic Review 39 (5): 859-887.

Collins, William J. 1996. "Regional Labor Markets in British India." Mimeo., Department of Economics, Harvard University (November).

Coppel, Jonathan and Martine Durand. 1999. "Trends in Market Openness." OECD Economics Department Working Papers 221. Paris: OECD.

Currie, Janet and Ann E. Harrison. 1997. "Sharing the Costs: The Impact of Trade Reform on Capital and Labor in Morocco." Journal of Labour Economics 15 (3): S44-S72.

Davis, Donald R. 1996. "Trade Liberalization and Income Distribution.” NBER Working Paper 5693. Cambridge, MA: National Bureau of Economic Research.

Deininger, Klaus and Lyn Squire. 1996. "A New Data Set Measuring Income Inequality." World Bank Economic Review 10 (3): 565-91.

Dowrick, Steve and Muhammad Akmal. 2001. "Explaining Contradictory Trends in Global Income Inequality: A Tale of Two Biases." Mimeo, Australian National University.

Dunning, John H. 1993. Multinational Enterprises and the Global Economy. New York: Addison-Wesley.

Eichengreen, Barry. 1993. "Labor Markets and European Monetary Unification." In Paul R. Masson and Mark P. Taylor, eds., Policy Issues in the Operation of Currency Unions. Cambridge: Cambridge University Press.

Feenstra, Robert C. and Gordon H. Hanson. 1996. "Foreign Investment, Outsourcing, and Relative Wages." In Robert C. Feenstra, Gene M. Grossman and Douglas A. Irwin, eds., The Political Economy of Trade Policy: Papers in Honor of Jagdish Bhagwati. Cambridge, MA: MIT Press.

Feis, Herbert. 1930. Europe, The World's Banker 1870-1914. New Haven, Conn.: Yale University Press.

Feldstein, Martin and Charles Horioka. 1980. "Domestic Saving and International Capital Flows." Economic Journal 90 (358): 314-29.

Findlay, Ronald and Kevin H. O'Rourke. 2001. "Commodity Market Integration in the Second Millennium." Paper presented at the NBER Globalization in Historical Perspective conference, Santa Barbara, CA, May 3-6, 2001.

Freeman, Richard B. and Remco H. Oostendorp. 2000. "Wages Around the World: Pay Across Occupations and Countries." NBER Working Paper 8058. Cambridge, MA: National Bureau of Economic Research.

Grossman, Gene M. and Elhanan Helpman. 1991. Innovation and Growth in the Global Economy. Cambridge, MA: MIT Press.

Hanson, Gordon H. and Ann E. Harrison. 1999. "Trade and Wage Inequality in Mexico." Industrial and Labor Relations Review 52 (2): 271-288.

Harley, C. Knick. 1980. "Transportation, the World Wheat Trade, and the Kuznets Cycle, 18501913." Explorations in Economic History 17 (3) : 218-50.

Hatton, Timothy J. and Jeffrey G. Williamson. 1998. The Age of Mass Migration: Causes and Economic Impact. Oxford: Oxford University Press. 
Hatton, Timothy J. and Jeffrey G. Williamson. 2001. "Demographic and Economic Pressure on Emigration Out of Africa." NBER Working Paper 8124. Cambridge, MA: National Bureau of Economic Research.

Higgins, Matthew and Jeffrey G. Williamson. 1999. "Explaining Inequality the World Round: Cohort Size, Kuznets Curves, and Openness." NBER Working Paper 7224. Cambridge, MA: National Bureau of Economic Research.

Hummels, David. 1999. "Have Intemational Transportation Costs Declined?" Mimeo, Purdue University.

Isserlis, L. 1938. "Tramp Shipping Cargoes and Freights." Journal of the Royal Statistical Society 101 (Pt. 1): 304-417.

Jones, Geoffrey. 1996. The Evolution of International Business: An Introduction. London: Routledge.

Jones, Matthew T. and Maurice Obstfeld. 1997. "Saving, Investment, and Gold: a Reassessment of Historical Current Account Data." NBER Working Paper 6103. Cambridge, MA: National Bureau of Economic Research.

Kanbur, Ravi. 1999. "Income Distribution Implications of Globalization and Liberalization in Africa." Mimeo, Cornell University.

Keller, Wolfgang. 2001. "The Geography and Channels of Diffusion at the World's Technology Frontier." NBER Working Paper 8150. Cambridge, MA: National Bureau of Economic Research.

Kuznets, Simon. 1955. "Economic Growth and Income Inequality." American Economic Review 45 (1): 1-28.

Lindert, Peter H. and Jeffrey G. Williamson. 2001. "Does Globalization Make the World more Unequal?' Paper presented at the NBER Globalization in Historical Perspective conference, Santa Barbara, CA, May 3-6, 2001.

Lucas, Robert E. 2000. "Some Macroeconomics For the $21^{\text {st }}$ Century." Journal of Economic Perspectives 14 (1): 159-168.

Melchior, Ame, Kjetil Telle, and Henrik Wiig. 2000. "Globalisation and Inequality: World Income Distribution and Living Standards, 1960-1998." Report 6B: 2000, Studies on Foreign Policy Issues. Oslo: Royal Norwegian Ministry of Foreign Affairs.

Milanovic, Branko. 1999. "True World Income Distribution, 1988 and 1993: First Calculations, Based on Household Surveys Alone." Working Paper 2244. Washington D.C.: World Bank Development Research Group.

Obstfeld, Maurice and Giovanni Peri. 1998. "Regional Non-Adjustment and Fiscal Policy." Economic Policy 26: 205-259.

Obstfeld, Maurice and Alan M. Taylor. 1998. "The Great Depression as a Watershed: International Capital Mobility in the Long Run." In Michael D. Bordo, Claudia D. Goldin and Eugene N. White, eds., The Defining Moment: The Great Depression and the American Economy in the Twentieth Century. Chicago: University of Chicago Press.

Obstfeld, Maurice and Alan M. Taylor. 2001. "Globalization and Capital Markets.” Paper presented at the NBER Globalization in Historical Perspective conference, Santa Barbara, CA, May 3-6, 2001.

O'Rourke, Kevin H., Alan M. Taylor, and Jeffrey G. Williamson. 1996. "Factor Price Convergence in the Late Nineteenth Century." International Economic Review 37 (3): 499-530. 
O'Rourke, Kevin H. and Jeffrey G. Williamson. 1997. "Around the European Periphery 18701913: Globalization, Schooling and Growth." European Review of Economic History 1 (2): 153-91.

O'Rourke, Kevin H. and Jeffrey G. Williamson. 1999. Globalization and History: The Evolution of a Nineteenth Century Atlantic Economy. Cambridge, MA: MIT Press.

O'Rourke, Kevin H. and Jeffrey G. Williamson. 2001. "After Columbus: Explaining the Global Trade Boom 1500-1800.” NBER Working Paper 8186. Cambridge, MA: National Bureau of Economic Research.

Pritchett, Lant. 1997. "Divergence, Big Time." Journal of Economic Perspectives 11 (3): 3-18.

Robbins, Donald J. 1996. "Evidence on Trade and Wages in the Developing World." OECD Technical Paper No. 119. Paris: OECD.

Rodríguez, Francisco and Dani Rodrik. 2001. "Trade Policy and Economic Growth: A Skeptic's Guide to the Cross-National Evidence." In Ben S. Bernanke and Kenneth Rogoff, eds., NBER Macroeconomics Annual 2000. Cambridge, MA: MIT Press.

Rodrik, Dani. 1999. The New Global Economy and Developing Countries: Making Openness Work. Washington, D.C.: Overseas Development Council.

Rodrik, Dani. 2000. "How Far Will International Economic Integration Go?' Journal of Economic Perspectives 14 (1): 177-186.

Sachs, Jeffrey D. and Andrew Warner. 1995. "Economic Reform and the Process of Global Integration." Brookings Papers on Economic Activity I. Washington, D.C.: Brookings Institution.

Schultz, T. Paul. 1998. "Inequality in the Distribution of Personal Income in the World: How it is Changing and Why." Journal of Population Economics 11 (3): 307-344.

Slaughter, Matthew J. 2001. "Trade Liberalization and Per Capita Income Convergence: A Difference-in-Differences Analysis." Journal of International Economics, forthcoming.

Spilimbergo, Antonio, Juan Luis Londoño and Miguel Székely. 1999. "Income Distribution, Factor Endowments, and Trade Openness." Journal of Development Economics 59 (1): 77-101.

Stokey, Nancy L. 1991. "Human Capital, Product Quality, and Growth." Quarterly Journal of Economics 106 (2): 587-616.

Taylor, Alan M. 1996. "International Capital Mobility in History: The Saving-Investment Relationship." NBER Working Paper 5743. Cambridge, MA: National Bureau of Economic Research.

Taylor, Alan M. 2000. "Latin America and Foreign Capital in the Twentieth Century: Economics, Politics, and Institutional Change." In Stephen H. Haber, ed., Political Institutions and Economic Growth in Latin America: Essays in Policy, History, and Political Economy. Stanford, CA: Hoover Institution Press.

Taylor, Alan M., and Jeffrey G. Williamson. 1994. "Capital Flows to the New World as an Intergenerational Transfer." Journal of Political Economy 102 (2): 348-71.

Taylor, Alan M., and Jeffrey G. Williamson. 1997. "Convergence in the Age of Mass Migration." European Review of Economic History 1 (1): 27-63.

UNCTAD. 2000. World Investment Report 2000. New York and Geneva: United Nations.

U.S. Department of Commerce. 1975. Historical Statistics of the United States: Colonial Times to 1970. Washington D.C.: Bureau of the Census. 
Williamson, Jeffrey G. 1995. "The Evolution of Global Labor Markets since 1830: Background Evidence and Hypotheses." Explorations in Economic History 32 (2): 141-196.

Williamson, Jeffrey G. 1997. "Globalization and Inequality, Past and Present." World Bank Research Observer 12 (2): 117-35.

Williamson, Jeffrey G. 1998. "Real Wages and Relative Factor Prices in the Third World Before 1940: What Do They Tell Us About the Sources of Growth?' HIER Discussion Paper 1855. Cambridge, MA: Harvard Institute for Economic Research.

Williamson, Jeffrey G. 2000. "Land, Labor and Globalization in the Pre-Industrial Third World." NBER Working Paper 7784. Cambridge MA: National Bureau of Economic Research.

Wood, Adrian. 1994. North-South Trade, Employment and Inequality: Changing Fortunes in a Skill-Driven World. Oxford: Clarendon Press.

Wood, Adrian. (1997), "Openness and Wage Inequality in Developing Countries: The Latin American Challenge to East Asian Conventional Wisdom." World Bank Economic Review 11 (1): 33-57.

World Bank. 2000. Global Development Finance 2000. Washington D.C.: World Bank. Zlotnik, Hania. 1999. "Trends of International Migration Since 1965: What Existing Data Reveal." International Migration 37 (1): 21-61. 
Table 1. Average tariffs on manufactured goods, selected countries, 1913-1998

\begin{tabular}{lccccc}
\hline & 1913 & 1931 & 1950 & 1980 & $1998 / 99$ \\
\hline Austria & 18 & 24 & 18 & 14.6 & NA \\
Belgium & 9 & 14 & 11 & NA & NA \\
Denmark & 14 & - & 3 & NA & NA \\
France & 20 & 30 & 18 & NA & NA \\
Germany & 13 & 21 & 26 & NA & NA \\
Italy & 18 & 46 & 25 & NA & NA \\
Netherlands & 4 & -- & 11 & NA & NA \\
Spain & 41 & 63 & -- & 8.3 & NA \\
Sweden & 20 & 21 & 9 & 6.2 & NA \\
UK & 0 & -- & 23 & NA & NA \\
EU & NA & NA & NA & 8.3 & 4.1 \\
Russia & 84 & $* *$ & $* *$ & $* *$ & $13.4^{\mathrm{a}}$ \\
Switzerland & 9 & 19 & -- & 3.3 & $3.2^{\mathrm{b}}$ \\
Australia & 16 & -- & -- & -- & 6 \\
Canada & 26 & -- & -- & -- & 4.9 \\
Japan & $25-30$ & -- & -- & 9.9 & 5.5 \\
New Zealand & $15-20$ & -- & -- & -- & 4.4 \\
USA & 44 & 48 & 14 & 7 & 4.5 \\
Argentina & 28 & -- & -- & -- & 14 \\
Brazil & $50-70$ & -- & -- & -- & 15.2 \\
Colombia & $40-60$ & -- & -- & -- & 11.4 \\
Mexico & $40-50$ & -- & -- & -- & 12.6 \\
China & $4-5$ & -- & -- & -- & 17.4 \\
India & approx. 5 & -- & -- & -- & 34.2 \\
Iran & $3-4$ & -- & -- & -- & -- \\
Thailand & $2-3$ & -- & -- & -- & $47.2^{\mathrm{c}}$ \\
Turkey & $5-10$ & -- & -- & -- & 0.25 \\
\hline
\end{tabular}

Sources: Bairoch (1989; 1993); World Development Indicators 2000.

Notes: NA $=$ not applicable; $-=$ not available; ${ }^{* *}$ refers to the fact that the USSR ran such a restrictive trade policy that average tariffs were irrelevant; ${ }^{a}=1997 ;{ }^{b}=1996 ;{ }^{c}=1993$. 
Table 2. Regional distribution of FDI stock, 1914-1999

$$
\text { (percent of total FDI stock) }
$$

\begin{tabular}{|c|c|c|c|c|}
\hline & \multicolumn{4}{|c|}{ FDI by origin } \\
\hline & 1914 & 1938 & 1960 & 1999 \\
\hline Developed countries & 100.0 & 100.0 & 98.9 & 89.9 \\
\hline North America & 19.2 & 30.4 & 52.0 & 27.5 \\
\hline USA & 18.2 & 27.7 & 48.3 & 23.8 \\
\hline Canada & 1.0 & 2.7 & 3.8 & 3.7 \\
\hline Western Europe & 75.4 & 63.9 & 42.1 & 54.1 \\
\hline UK & 44.6 & 39.8 & 16.3 & 14 \\
\hline Germany & 10.3 & 1.3 & 1.2 & 8.8 \\
\hline France & 12.0 & 9.5 & 6.2 & 6.3 \\
\hline Other western Europe & 8.6 & 13.3 & 18.3 & 25 \\
\hline Russia & 2.1 & 1.7 & 0.0 & 0.2 \\
\hline Japan & 2.1 & 2.8 & 0.8 & 6.2 \\
\hline Developing countries & 0.0 & 0.0 & 1.1 & 9.8 \\
\hline \multirow[t]{3}{*}{ Total } & 100 & 100 & 100 & 100 \\
\hline & \multicolumn{4}{|c|}{ FDI by host } \\
\hline & 1914 & 1938 & 1960 & 1999 \\
\hline Developed countries & 37.2 & 34.3 & 67.3 & 67.7 \\
\hline North America & 16.0 & 16.8 & 37.6 & 26.3 \\
\hline USA & 10.3 & 7.4 & 13.9 & 22.8 \\
\hline Canada & 5.7 & 9.4 & 23.7 & 3.5 \\
\hline Western Europe & 7.8 & 7.4 & 22.9 & 36.8 \\
\hline UK & 1.4 & 2.9 & 9.2 & 8.3 \\
\hline Other Europe & 9.9 & 1.6 & 0.9 & 2.4 \\
\hline Russia & 7.1 & 0.0 & 0.0 & 0.3 \\
\hline Australasia and S. Africa & 3.2 & 8.0 & 6.6 & 3.5 \\
\hline Japan & 0.2 & 0.4 & 0.2 & 0.8 \\
\hline Developing countries & 62.8 & 65.7 & 32.3 & 30.1 \\
\hline Latin America & 32.7 & 30.8 & 15.6 & 10.2 \\
\hline Africa & 6.4 & 7.4 & 5.5 & 2 \\
\hline Asia & 20.9 & 25.0 & 7.5 & 17.7 \\
\hline China & 7.8 & 5.8 & 0.0 & 6.4 \\
\hline India and Ceylon & 3.2 & 5.6 & 2.0 & 0.4 \\
\hline Middle East & 2.8 & 2.6 & 2.8 & 1.3 \\
\hline
\end{tabular}

Source: Dunning (1993); UNCTAD (2000). 
Table 3 . Inequality in the late $20^{\text {th }}$ century

\begin{tabular}{|c|c|c|c|c|}
\hline & $1960 \mathrm{~s}$ & $1970 \mathrm{~s}$ & $1980 \mathrm{~s}$ & $1990 \mathrm{~s}$ \\
\hline \multicolumn{5}{|l|}{ OECD } \\
\hline Gini coefficient & 34.7 & 33.6 & 32.6 & 33 \\
\hline Q5/Q1 ratio & 6.94 & 6.64 & 6.2 & 6.49 \\
\hline No. of countries & 12 & 19 & 20 & 13 \\
\hline \multicolumn{5}{|l|}{ Africa } \\
\hline Gini coefficient & 45.3 & 49.8 & 41.6 & 46.4 \\
\hline Q5/Q1 ratio & 12.2 & 17.5 & 9.63 & 12.88 \\
\hline No. of countries & 4 & 4 & 11 & 15 \\
\hline \multicolumn{5}{|l|}{ Latin America } \\
\hline Gini coefficient & 53.6 & 50.4 & 50.1 & 50 \\
\hline Q5/Q1 ratio & 21.2 & 17 & 16.2 & 13.3 \\
\hline No. of countries & 6 & 12 & 12 & 10 \\
\hline \multicolumn{5}{|l|}{ Pacific Rim } \\
\hline Gini coefficient & 37.4 & 39 & 38.5 & 39.2 \\
\hline Q5/Q1 ratio & 8.28 & 8.96 & 7.88 & 8.14 \\
\hline No. of countries & 6 & 9 & 10 & 7 \\
\hline
\end{tabular}

Source: Higgins and Williamson (1999), based on Deininger and Squire (1996). 
Figure 1. Capital flows, 1870-1992

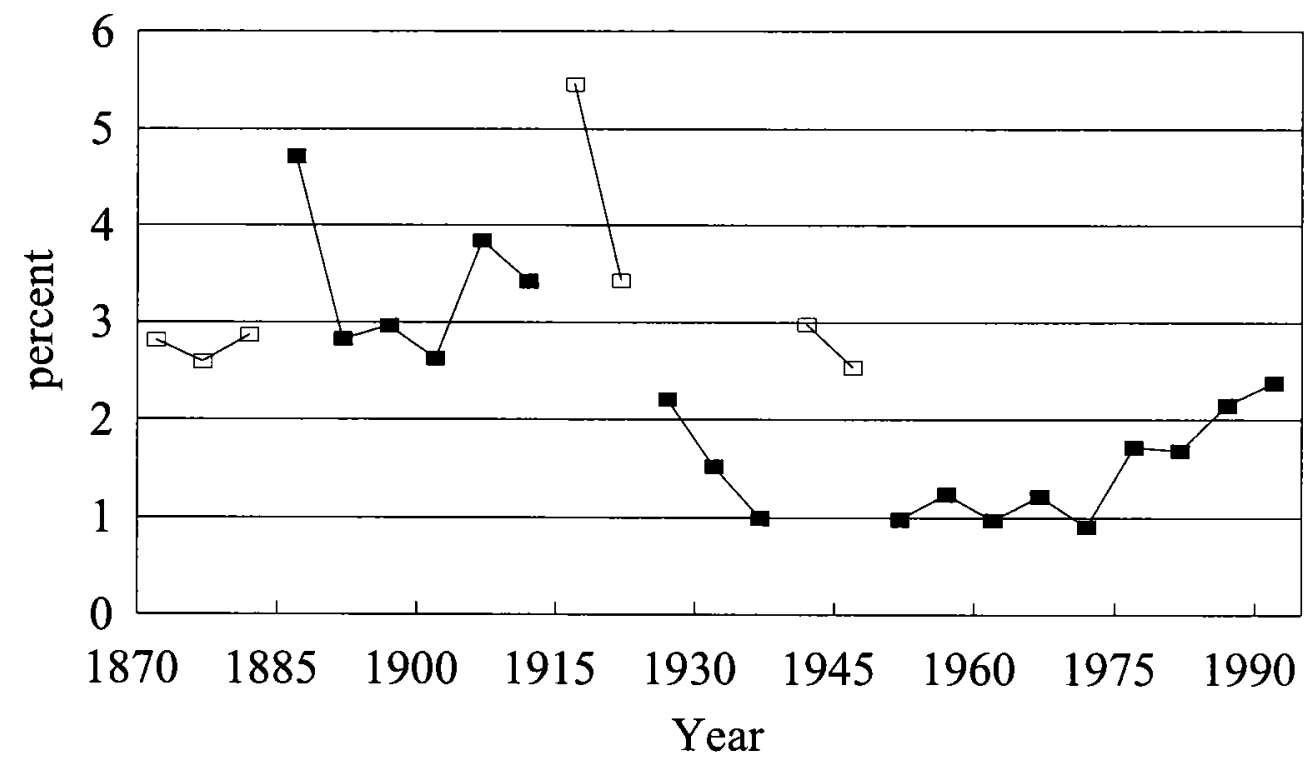

$\neg$ - Complete sample $\square$ Missing countries 
Figure 2. World inequality, 1820-1992

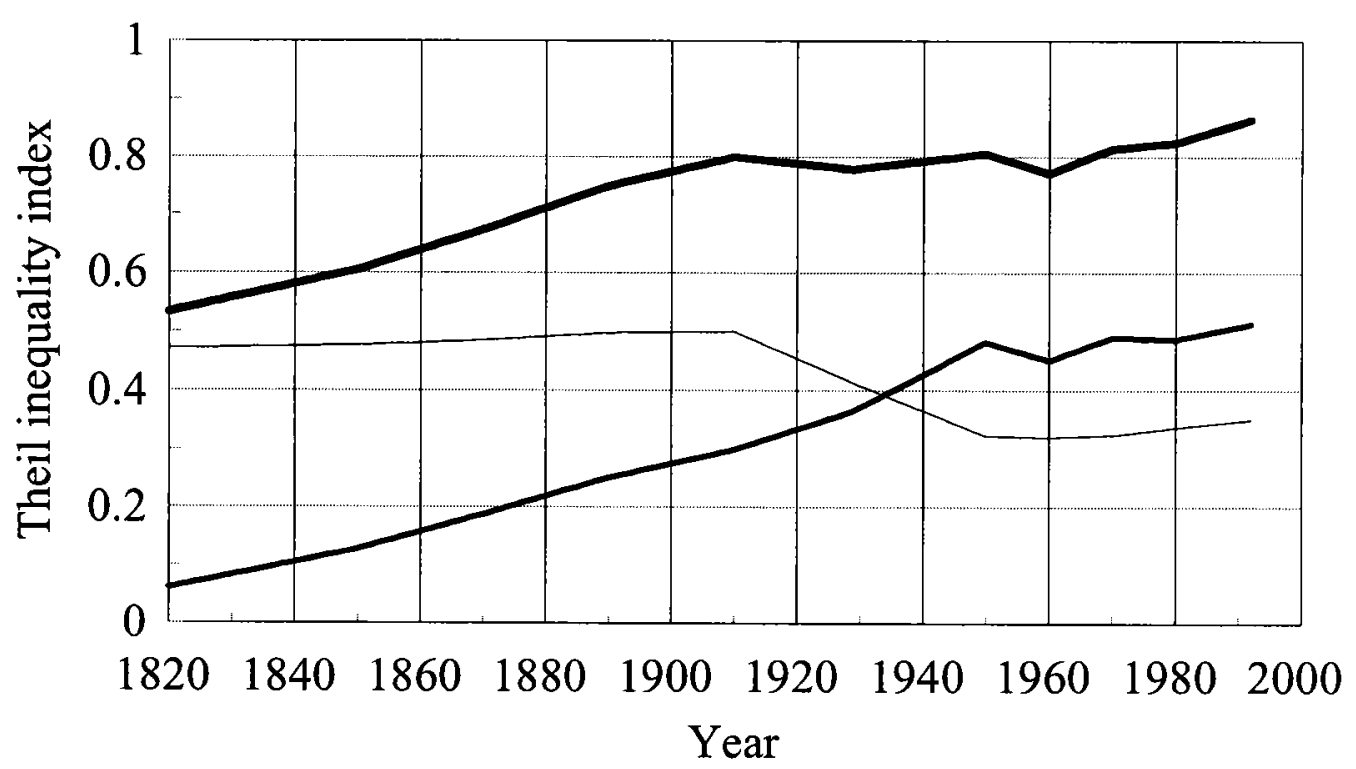

Within-country inequality $\longrightarrow$ Between-country inequality $\longrightarrow$ Total inequality

Source: Bourguignon and Morrisson (1999). 